\title{
An analysis of terminology use in place branding
}

Received (in revised form): 10th September, 2007

\author{
Sonya Hanna \\ is a PhD candidate at Bangor Business School. She holds an MBA in General Management.
}

\section{Jennifer Rowley}

is Professor of Information and Communications at Manchester Metropolitan University, and was previously Professor of Marketing and Information Management at Bangor University.

\begin{abstract}
The inception of place branding evolved from research within various fields including place image and marketing. The literature reports on studies focusing on the application of the branding concept to various geographical entities ranging from countries to towns and the challenges of branding the multidimensional construct 'place' especially in relation to stakeholder engagement. There seems to be a recognisable gap in the literature regarding the application of the term 'place' and its associated vocabulary: location, country, nation, city and region. While a 'destination' indicated tourism only, there is no agreed language for the holistic or all encompassing brand. This exploratory research attempts to identify the application of the term 'place' and it associated vocabulary. The application of place brand terms was examined by discipline and in relation to geographical entities using the sample population of place-branding case-study research. Content analysis was used to elicit place brand terms and geographical entities within various articles published in various disciplines. The data were analysed using the chi-square test for independence. The content analysis affirmed that the focus of place branding has shifted from the discipline of tourism to branding and business. The research also affirmed that a 'destination' indicates tourism only, articulated in various geographical entity forms, while the absence of 'town' as a possible place brand term became apparent as did the lack of case-study research relating to towns; countries and cities commanded the majority share of the case-study research. The results of the study depict the application of place brand terms in a generic manner from which guidance for the specific application of place terms may provide future consensus either implicitly or through the formation of distinctive place term definitions.

Place Branding and Public Diplomacy (2008) 4, 61-75. doi:10.1057/palgrave.pb.6000084
\end{abstract}

Keywords: Place branding, place terminology, destination branding, place marketing

Correspondence: Sonya Hanna,

Bangor Business School Bangor University Hen Goleg College Road Bangor, Gwynedd Wales LL57 2DG, UK. Tel: +4407748 103932 e-mail: abp405@bangor.ac.uk/ sonyahanna80@hotmail.com

\section{INTRODUCTION}

Place branding has gained visibility as one of the hot topics among academics and practitioners. Given that places are increasingly facing global competition in both their external and domestic markets, the application of branding techniques to places is growing in frequency. Research based on the branding practices of various geographical entities (countries, regions, cities, towns) has accentuated the challenges of branding the multidimensional 
construct 'place'. Additionally, contributions from various texts ${ }^{1}$ that range in terms of the politics of branding places, branding and national identity, and destination branding on the web have augmented place-branding literature while the creation of the Journal of Place Branding has provided a comprehensive and coherent forum with which to drive the discipline forward.

Re-current themes within the various disciplines that discuss place branding include: comparisons between branding a product/ service and destinations/cities (Gnoth, 2002; Cai, 2002; Parkerson and Saunders, 2005; Kavaratzis and Ashworth, 2005); comparison between corporate branding and city brands (Olins, 2003; Trueman et al., 2004; Kavaratzis, 2004) and similarity to corporate umbrella branding (Papadopolos and Heslop, 2002; Gnoth, 2002); impressions between place branding and (re)positioning (Gilmore, 2002a,b); image building and reconstruction

(Curtis, 2001; Hall, 2004); the importance of unique identity and use of branding elements (Cai, 2002); and the role of emotional links with consumers (Hall, 2004; Gilmore, 2002b).

In addition, a wide range of other themes have been explored, including: the application of branding concepts on different geographical entities using corporate identity methodology to examine interface dissonance (Trueman et al., 2004); the investigation of collaborative destination branding considering various characteristics and industry structures within different destinations (Wang and Fesenmaier, 2006); the investigation of stakeholder brand relationships to identify the extent to which place brand management is a collective activity embraced by the local community (Morgan, 2004); the provision of criteria for brand success as the basis for the analysis of 'place' branding practices (Rainisto, 2004; Gnoth, 2004); exploration of the relationship between culture and branding given that it is the cultural difference of a 'place' that permeate differentiation (Morgan, 2003; Hankinson, 2005); and, evaluating the presence of neighbouring images prevailing on the 'place' brand (Cai, 2002).

Given the dynamic and growing nature of the academic discipline of place branding coupled with increased practitioner interest, Lodge $(2004,2006)$ called for the development of an agreed place-branding vocabulary. This paper takes one step in this direction exploring the use of place terms such as place, location, destination, country, nation, city and regions within the two broad discipline groups of business and branding, and tourism. Further, the research goes on to analyse the use of these terms to refer to branding initiatives associated with different geographical entities. The paper starts with a brief review of the importance of place branding, and its development. The next section summarises other authors' discussions of the use of various place terms, and on this basis proposes a model of the relationships between the meanings of such terms. The methodology for the analysis undertaken in this project is discussed next, and this leads into an analysis of the findings. Finally, conclusions are outlined and further research is proposed.

\section{PLACE BRANDING AND ITS DEVELOPMENT}

Branding as a construct can be traced back to the late 19th century with the development of branded consumer goods such as Quaker Oats and Gillette (Low and Ronald, 1994). A definition of a brand was originally provided by the American Marketing Association as 'a name, term, sign, symbol or design, or a combination of these intended to identify the goods and services of one seller or a group of sellers and to differentiate them from those of competitors' (Kotler et al., 2002: 469). Although criticised for being too product oriented, this definition has endured contemporary literature (Wood, 2000) and is viewed as a common starting point for works associated with brands (Kerr, 2006). Further, McGnally et al. (1999) identified the post-modern approaches of 'brand as company' (p. 2) and 'brand as policy' (p. 3): disseminating the dependence of applying branding concepts to consumer products to include all physical 
entities, hence the expanding application of branding to include corporations, destinations and more recently places.

Among the conditions that make place branding a necessity is the growing power of international media, the falling cost of international travel, rising consumer spending power, the threat of place parity, a scarce pool of international investors, competition for skilled and professional immigrant's and growing consumer demand for a diverse cultural diet stimulated by low-cost global communication media. To be precise, place branding, both as a necessity and a phenomenon, is mainly provoked by globalisation processes where the market place for ideas, culture, reputation, in addition to products, services and funds are fusing into a single global community (Anholt, 2005). People can now simply work and live almost anywhere, abandoning failing and deteriorating places for ones offering growing opportunities (Kotler, 2004). Places are and have always been subject to 'internal growth and decline cycles [along with] external shocks and forces beyond their control' (Kotler et al., 1993: 4). Therefore, whether at the national, regional, city or town level, branding is as much a way of planning developmental policies as branding in the private sector is about business strategy.

Globalisation has created a competitive arena where newly developing places can now compete with the charm and appeal of older more established places. Unless the latter retain and enhance resources, outward migration is inevitable; residents wish for opportunity-filled places in order to exercise their individual skills and interests and to have 'pride of place' (Kotler, 2004: 12). As visitors, investors and residents, we all tend to seek 'the harmonious city' (p. 472) where various aspects of comfort, economic development and political stability can satisfy our individual and differentiated requirements (Paddison, 1993).

Accordingly, place managers need to become involved in the formation of a brand identity that accords the multidimensional construct 'place' purpose and direction, while the brand's delivery on attributes, benefits, values and personality secures consumer satisfaction, and economic and political attention (van Ham, 2004).

The study of place branding extends across a wide range of academic areas (Hankinson, 2001); however, it is in the sphere of travel tourism, defined as a life away from home, that an understanding of place branding is most developed, hence the primary focus of the branding literature (Hankinson, 2005). Studies on destination image as a concept of branding theory began in the early 1970s through Hunt's influential works on the role of image in tourism development (Hunt, 1975). Branding theories within the context of leisure tourism began to gain visibility in 1998 as the focal topic of the Annual Travel and Tourism and Research Association's Conference (Blain et al., 2005); destination branding is defined as 'name, symbol, logo, word or other graphic that both identifies and differentiates the destination ... [while] convey[ing] the promise of a memorable travel experience ... [as well as] serv[ing] to consolidate and reinforce the recollection of pleasurable memories of the destination experience' (Ritchie and Ritchie, 1998: 17).

Practitioners' perspectives on destination branding argue for leveraging gains from tourism marketing for further economic development (Kotler and Gertner, 2002; Gnoth, 2002; Park and Petrick, 2006), the rationale being that the most arresting aspect of place brand images are quite often to be found in tourism marketing efforts (Sundaram, 2007). Further, destination branding consultants proclaim that 'destination branding refers to efforts to increase tourist visits and tourist spending for a particular travel destination' (Whisper: brand strategy consultants) and that 'a destination can be anything from a nation to a region, a resort to a city, an attraction to an event ...' (The Hat Factory: Destination Branding).

The forgoing affirms that a destination brand represents a single industry, tourism and a destination is an aspect within the conceptual entity 'place'. On the other hand, a destination brand has the potential to serve as a 
'coordinating symbol for a broad range of community developments and promotion efforts, many of which may fall outside the normal responsibility of tourism DMO [destination management organisation]' (Ritchie and Ritchie, 1998: 19). This supports the notion that place branding has transcended into a composite construct that not only encompasses tourism but also economic, socio-political and historical prospects (Gnoth, 2002; Papadopoulos and Heslop, 2002, van Ham, 2001; Olins, 2002). Dinnie (2004) postulates that there exists a strong argument for place branding to transcend the confines of a single industry in order to achieve a more cohesive image. Subsequently, Anholt (2004, cited in Kerr (2006)) defined place branding as 'the practice of applying brand strategy and other marketing techniques and disciplines to the economic, social, political and cultural developments of cities, regions and countries' (Kerr, 2006: 278), asserting that holistic place branding 'encompasses everything a place wishes to sell' (Lodge, 2006: 9). It is now widely acknowledged that the 'understandings and experiences of places are mediated by a range of everyday texts through which landscapes are presented' (Gibson and Davidson, 2004: 390).

In addition to the work on leisure tourism, research has focused on four forms of place branding: business tourism (Ulaga et al., 2002; Bradley et al., 2002; Hankinson, 2005); culture, including gastronomy (Sharples, 2003; Roberts and Hall, 2001; Telstrom et al., 2006, Waragenau and Che, 2006); sports (Smith, 2005; Chalpin et al., 2003); and film, literature and music (Hudson and Ritchie, 2006; Johns and Mattsson, 2005; Gibson and Davidson, 2004).

\section{'PLACE' AND ASSOCIATED VOCABULARY}

The general supposition that a 'destination' brand denotes the tourism dimension of a place is widely supported. The complexity of identifying a single destination, however, is complicated by the fact that a destination may include several towns, cities or municipalities, other government provinces or even an island archipelago may be the entire country; place branding, travel, tourism and brand management literature provide ample evidence of the forgoing (Morgan et al., 2004; Bramwell and Rawding, 1996; Wilson et al., 2001; O’Leary and Deegan, 2005; Baloglu and McCleary, 1999; Kerr, 2006). Decorously, the form of geographical entity does not limit the scope of destination branding provided a direct association with tourism is established, although it has been noted that destination branding has been conflated with nation branding (Anholt, 2005).

Perceived as a 'whole', it is argued that the components of nations, defined as 'a country, especially when thought of as a large group of people living in one area with their own government, language, traditions etc' (Cambridge Dictionary Online), such as tourism, agriculture and entertainment, can be individually promoted and sold, but by definition, nations are unlikely to have a single target market or offering (Anholt, 2005). To clarify, just as companies such as General Motors and Procter and Gamble offer various distinct products to the market so do countries produce 'outputs' that consist of products, services and actions of their governments, exporters and industry associations (Papadopoulos and Heslop, 2002). Therefore, when referring to the importance of nation brands in relation to countries, the reference is in the context of country 'outputs' which within the context of tourism is a destination brand.

Lodge (2004: 33) asserts that 'if destination branding (tourism only) is well established, the same cannot yet be said of what might be termed location branding (which may include any or all of investment, exports, tourism, education, culture, sports, events and attracting back exports)'. Morgan (2006: 12) affirms that within the context of tourism his studies have particularly focused on 'destination branding within the wider strategy of location branding'. Accordingly, a 'location' brand implies the branding of a composite construct: a 'place'.

Therefore, comparatively and by implication a Nation can equate to a Place; on a smaller scale, while a Location is a place in as far as 
places are defined as cities, towns and rural regions (Cambridge Dictionary Online), all of which may produce their own 'outputs'. Based on the aforementioned conceptualisations, Figure 1 illustrates the hierarchical relationship between 'place' and its associated vocabulary encompassing a range of brand dimensions including destination brands (leisure tourism).

Alternatively, the lack of a clear academic distinction between 'place' and its associated vocabulary may be pure semantics.

\section{METHODOLOGY}

While it is possible to divine some definitions of place terms, it is not evident that they are always used consistently. Accordingly, this research sets out to establish the use of place terms in different disciplines, and, in relation to different geographical entities. The research was conducted from the perspective of 'applied' terms to geographical entities and did not consider the 'correct' application of applied terms in relation to the form of geographical entity. As this was an exploratory study, it was felt inappropriate to develop formal hypotheses. The research was therefore guided by two research questions:

RQ1: Are place terms applied proportionately across various disciplines?

RQ2: Is there a relationship between the application of specific place terms and geographical entity?

The methodology involved the identification of as many case-study papers published in academic journals in the area of place branding as possible. The relevant journals were found to be broadly in the business and branding areas and in tourism. A range of search tools were used to establish the data set, including Emerald Full-text and Management Review, Ingenta Connect, Sage, Web of Knowledge and Google Scholar. The search procured a total of 67 papers in 12 journals. In some instances, the researchers' judgment was used to determine the nature of the paper as a 'case-study' as it

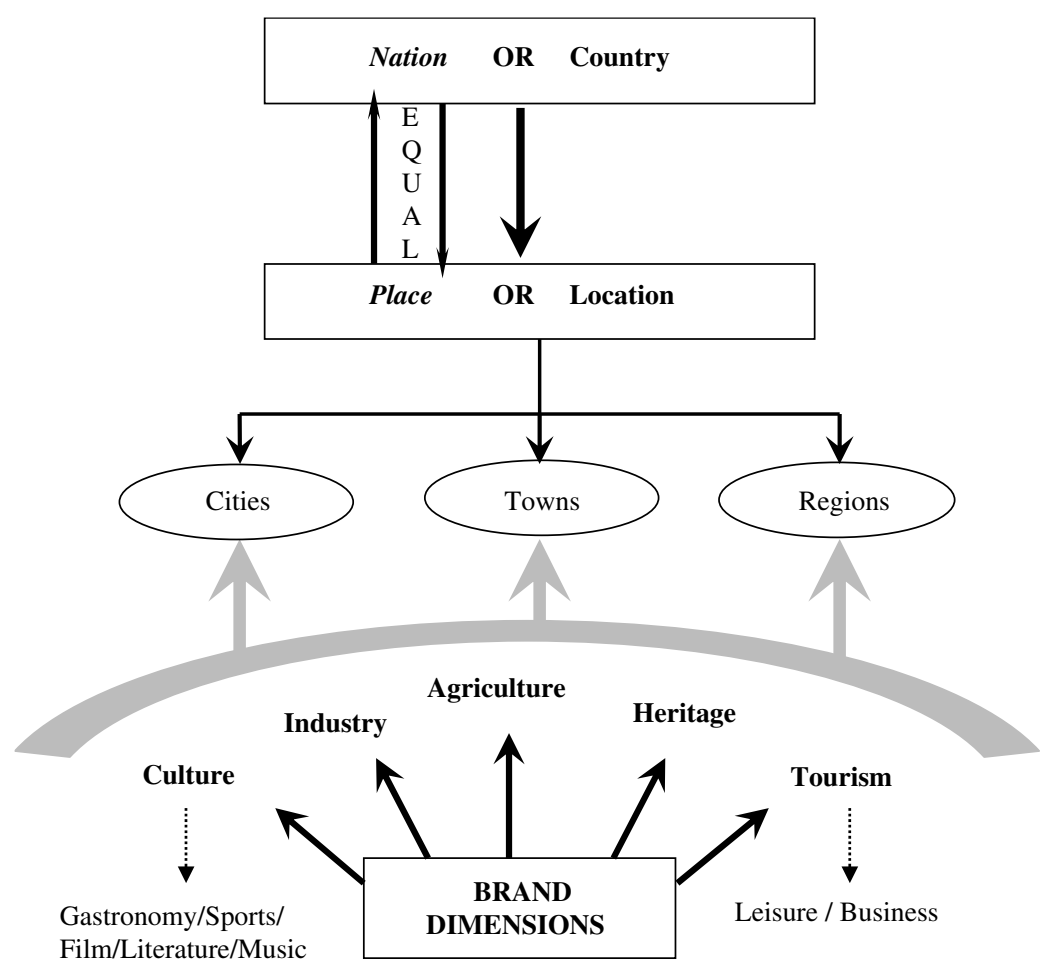

Figure 1: 'Place' and Associated Vocabulary 
Table 1a: Place term used (unit of analysis)

\begin{tabular}{l} 
Place \\
Location \\
Destination \\
Country \\
Nation \\
City \\
Region \\
\hline
\end{tabular}

Table 1b: Geographical entity descriptors

\begin{tabular}{l} 
Region \\
City \\
Country \\
Town \\
Resort \\
State \\
Province \\
County \\
\hline
\end{tabular}

was not made profusely clear, reducing the number of journals to 11 encompassing a total of 59 papers. To ensure greater accuracy and substance, papers before 2000 were omitted as it was felt that the emerging discipline of 'place branding' pre-2000 was not clearly established due to a certain degree of conflation with place image and marketing.

An analysis was undertaken of the use of place terms in the identified data set. A content analysis, an 'objective, systematic and quantitative description of the manifest content of a communication' (Malhotra, 2004: 189), of the paper title and its abstract was undertaken to identify the use of specific place brand terms. A content analysis of entire papers would have been extremely time consuming and may have even resulted in some confusion. The number of case studies recorded was dependent on the number of geographical entities mentioned in each paper. Therefore, a 'case-study' paper was recorded according to geographical entities 'studied' (see Appendix A); a total of 89 case studies were analysed. The latter was deemed necessary if the study was to analyse the 'application' of place terms within disciplines and in relation to geographical entities accurately. Tables $1 \mathrm{a}$ and $1 \mathrm{c}$ display the deduced categorical variables of place terms used and the
Table 1c: Journal discipline

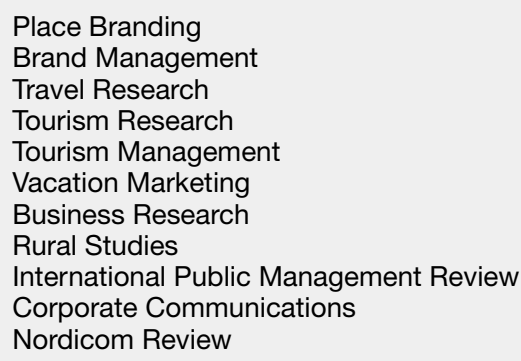

journal disciplines for analysis. The researchers' judgment was used to decide geographical entity place descriptors used either within the article title and/or the abstract. For instance, the entity descriptor for 'Branding Britain' would be country, A Distorted Destination Image: the case of Turkey would also be country and so forth. Geographical entity descriptors are displayed in Table $1 \mathrm{~b}$.

\section{DATA ANALYSIS}

The research questions were addressed using the chi-square test for independence; the test is used to investigate the relationship between two categorical variables, each with two or more categories based on the null hypotheses that the two variables do not affect each other (Pallant, 2006: 288). Once administered, a cross-tabulation $^{2}$ is automatically performed to validate the assumption of the minimum expected cell frequency ${ }^{3}$ (Malhotra, 2004: 438). The data were analysed using the categorical variables depicted by Tables $1 \mathrm{a}-1 \mathrm{c}$. On the basis of this initial analysis, the categorical variables were consolidated as shown in Tables $2 \mathrm{a}$ and $2 \mathrm{~b}$, respectively.

'Resort' was omitted as it was felt that a total of one paper investigating resorts as destinations would further obscure the cross-tabulation. Similarly, the purpose of Nordicom Review was to provide media-based research, which was felt to be too specific to be grouped in either discipline. Place brand terms used were not combined as that would have violated the purpose of the study, to establish how each place term is applied by discipline and in relation to 
Table 2a: Geographical entity descriptors

\begin{tabular}{l} 
Region/State/County/Province \\
City \\
Country \\
Town \\
\hline
\end{tabular}

Table 2b: Discipline

\begin{tabular}{ll}
\hline Branding and Business & Tourism \\
\hline Place Branding & Journal of Travel Research \\
Journal of Brand & Annals of Tourism \\
Management & Research \\
Journal of Business & Journal of Tourism \\
Research & Management \\
Journal of Rural Studies & Journal of Vacation \\
& Marketing \\
International Public & \\
Management Review & \\
Corporate & \\
Communications, an & \\
International Journal & \\
\hline
\end{tabular}

geographical entities. The cross-tabulation of the collated variables was analysed to determine the frequency of application of place brand terms used. The analysis of the collated variables was deemed more appropriate and necessary to reduce complexity and to produce meaningful interpretations of variable associations.

\section{RESULTS AND DISCUSSION}

On initial administration of the chi-square test, the minimum expected cell frequency was violated by 75 cells for RQ1 and 51 cells for RQ2 (see Appendix B: Tables B1 and B2, respectively). The results obtained from the collated variables also revealed a violation by seven cells for RQ1 and 23 cells for RQ2 (see Appendix B: Tables B3 and B4, respectively). It was therefore concluded that there are too many different place brand terms used in the sample population. This meant that the chisquare tests could not be used to establish the presence or lack of a significant difference in the application of place brand terms by discipline and geographical entity.

The results obtained from the cross-tabulation of the combined variables reveal that in relation to RQ1 (Table 3a), studies within the discipline
Table 3a: Cross-tabulation: Place brand term vs. discipline

\begin{tabular}{|c|c|c|c|}
\hline & \multicolumn{2}{|l|}{ Discipline } & \multirow[t]{2}{*}{ Total } \\
\hline & $\begin{array}{l}\text { Branding } \\
\text { and } \\
\text { business }\end{array}$ & Tourism & \\
\hline \multicolumn{4}{|l|}{ Place brand term used } \\
\hline Count & 15 & 0 & 15 \\
\hline$\%$ within discipline & 25.9 & 0 & 16.9 \\
\hline$\%$ of Total & 16.9 & 0 & 16.9 \\
\hline \multicolumn{4}{|l|}{ Location } \\
\hline Count & 12 & 1 & 13 \\
\hline$\%$ within discipline & 20.7 & 3.2 & 14.6 \\
\hline$\%$ of Total & 13.5 & 1.1 & 14.6 \\
\hline \multicolumn{4}{|l|}{ Destination } \\
\hline Count & 6 & 29 & 35 \\
\hline$\%$ within discipline & 10.3 & 93.5 & 39.3 \\
\hline$\%$ of total & 6.7 & 32.6 & 39.3 \\
\hline \multicolumn{4}{|l|}{ Country } \\
\hline Count & 8 & 0 & 8 \\
\hline$\%$ within discipline & 13.8 & 0 & 9.0 \\
\hline$\%$ of total & 9.0 & 0 & 9.0 \\
\hline \multicolumn{4}{|l|}{ Nation } \\
\hline Count & 10 & 0 & 10 \\
\hline$\%$ within discipline & 17.2 & 0 & 11.2 \\
\hline$\%$ of total & 11.2 & 0 & 11.2 \\
\hline \multicolumn{4}{|l|}{ City } \\
\hline Count & 3 & 1 & 4 \\
\hline$\%$ within discipline & 5.2 & 3.2 & 4.5 \\
\hline$\%$ of total & 3.4 & 1.1 & 4.5 \\
\hline \multicolumn{4}{|l|}{ Region } \\
\hline Count & 4 & 0 & 4 \\
\hline \%within discipline & 6.9 & 0 & 4.5 \\
\hline$\%$ of total & 4.5 & 0 & 4.5 \\
\hline \multicolumn{4}{|l|}{ Total } \\
\hline Count & 58 & 31 & 89 \\
\hline$\%$ within discipline & 100.0 & 100.0 & 100.0 \\
\hline$\%$ of total & 65.2 & 34.8 & 100.0 \\
\hline
\end{tabular}

of Branding and Business (65.2 per cent) are double those in Tourism (34.8 per cent); the focus of discussion for place branding seems to have shifted from tourism to business and marketing. The totals for both disciplines depicted 'Destination' (39.3 per cent) as the overall re-current brand term used, supporting the supposition that 'Destination' branding is the primary focus of place branding literature (Hankinson, 2005) and that a 'Destination' brand indicates tourism only (Lodge, 2006).

At 4.5 per cent, the brand term 'city' is the least used by both disciplines, indicating a recognisable gap in the literature as observed by Anholt (2002) and Hankinson (2001), who also postulate that branding as a concept is increasingly being applied to locations; at 20.7 
per cent, 'Location' branding is second to 'Place' within Branding and Business and a close third in total (14.6 per cent) post place (16.9 per cent).

The brand term 'Place' accounts for 25.9 per cent, the highest total percentage, in Branding and Business while for Tourism 'Destination' accounted for 93.5 per cent of the total; the other 10.3 per cent of the total was possibly due to the holistic nature of Branding and Business ergo accounting for a degree of overlap with Tourism. Further, an association was only deduced between Branding and Business and the place terms 'Place', 'Country', 'Nation' and 'Region' indicated by 0 per cent case studies relating to Tourism; a consequence that may relate to the holistic nature of the journals defining Branding and Business that is congruent with the aforementioned place terms by definition.

In relation to RQ2 (Table $3 b$ ), most studies are related to Countries (52.8 per cent) although a significant number (32.6 per cent) investigated the branding of Cities, the visibility of country and city branding initiatives being more pronounced due to the availability of continuous and greater funding for place marketers (Morgan et al., 2004: 62). 6.7 per cent of studies investigated the branding of towns. More significantly, the branding practices of Regions, States, Counties and Provinces accounted for 7.9 per cent of the total. The totals for geographical entity descriptors depict 'Destination' (37.1 per cent) as the dominant re-current brand term used; a smaller variation was observed between 'Place' (16.9 per cent) and 'Location'

Table 3b: Cross-tabulation: Place brand term vs. geographical entity

\begin{tabular}{|c|c|c|c|c|c|}
\hline & \multicolumn{4}{|c|}{ Geographical entity descriptor (GED) } & \multirow[t]{2}{*}{ Total } \\
\hline & $\begin{array}{l}\text { Region/State/ } \\
\text { County/Province }\end{array}$ & City & Country & Town & \\
\hline \multicolumn{6}{|l|}{ Place brand term used } \\
\hline \multicolumn{6}{|l|}{ Place } \\
\hline Count & 2 & 3 & 10 & 0 & 15 \\
\hline \% within GED & 28.6 & 10.3 & 21.3 & 0 & 16.9 \\
\hline$\%$ of total & 2.2 & 3.4 & 11.2 & 0 & 16.9 \\
\hline \multicolumn{6}{|l|}{ Location } \\
\hline Count & 0 & 7 & 1 & 5 & 13 \\
\hline$\%$ within GED & 0 & 24.1 & 2.1 & 83.3 & 14.6 \\
\hline$\%$ of total & 0 & 7.9 & 1.1 & 5.6 & 14.6 \\
\hline \multicolumn{6}{|l|}{ Destination } \\
\hline Count & 3 & 11 & 18 & 1 & 33 \\
\hline$\%$ within discipline & 42.9 & 37.9 & 38.3 & 16.7 & 37.1 \\
\hline$\%$ of total & 3.4 & 12.4 & 20.2 & 1.1 & 37.1 \\
\hline \multicolumn{6}{|l|}{ Country } \\
\hline Count & 1 & 0 & 7 & 0 & 8 \\
\hline \% within GED & 14.3 & 0 & 14.9 & 0 & 9.0 \\
\hline$\%$ of total & 1.1 & 0 & 7.9 & 0 & 9.0 \\
\hline \multicolumn{6}{|l|}{ Nation } \\
\hline Count & 0 & 0 & 10 & 0 & 10 \\
\hline \% within GED & 0 & 0 & 21.3 & 0 & 11.2 \\
\hline$\%$ of total & 0 & 0 & 11.2 & 0 & 11.2 \\
\hline \multicolumn{6}{|l|}{ City } \\
\hline Count & 0 & 6 & 0 & 0 & 6 \\
\hline$\%$ within GED & 0 & 20.7 & 0 & 0 & 6.7 \\
\hline$\%$ of total & 0 & 6.7 & 0 & 0 & 6.7 \\
\hline \multicolumn{6}{|l|}{ Region } \\
\hline Count & 1 & 2 & 1 & 0 & 4 \\
\hline \% within GED & 14.3 & 6.9 & 2.1 & 0 & 4.5 \\
\hline$\%$ of total & 1.1 & 2.2 & 1.1 & 0 & 4.5 \\
\hline \multicolumn{6}{|l|}{ Total } \\
\hline Count & 7 & 29 & 47 & 6 & 89 \\
\hline$\%$ within GED & 100.0 & 100.0 & 100.0 & 100.0 & 100.0 \\
\hline$\%$ of total & 7.9 & 32.6 & 52.8 & 6.7 & 100.0 \\
\hline
\end{tabular}


(14.6 per cent), 'Nation' (11.2 per cent) and 'Country' (9.0 per cent), and 'City' (6.9 per cent) and 'Region' (4.5 per cent), supporting the literature that a 'Destination' may take several forms.

At the town level, the term 'Location' dominated the literature (83.3 per cent); the term 'Place' was not used ( 0 per cent) considering by definition place and location equate (Cambridge Dictionary Online). 'Place' and 'Location' had a presence in the literature in relation to cities (10.3 and 24.1 per cent, respectively) and countries (21.3 and 2.1 per cent, respectively), supporting their hierarchical status depicted in Figure 1. It should be noted that initial observations from the content analysis did not depict 'Town' as a possible place term and hence its absence in Tables $1 \mathrm{a}$ and $2 \mathrm{a}$.

'Destination' was most used in relation to the combined entities Region, State, County and Province (42.9 per cent), followed by countries (38.3 per cent), cities (37.9 per cent) and a significantly lower rate for towns (16.7 per cent).

There was a significant variation in the application of place brand term's 'Country' (14.9 per cent) and 'Nation' (21.3 per cent) in relation to countries. Although defined as a country, reference to 'Nation' brands may also incorporate country 'outputs' (Papadopoulos and Heslop, 2002) encompassing the various brand dimensions discussed in the literature and depicted in Figure 1. A complete lack of case studies was observed for entity descriptors Region, State, County and Province, indicating unanimity in regard to the definition of a 'Nation' as a country (Cambridge Dictionary Online). The presence of 14.3 per cent 'Country' case studies within the entity descriptors Region, State, County and Province, however, is also conceivable based on the understanding of self-governance. Perhaps to evade the foregoing confluence, greater association is observed between 'Place' and a Region, State, County and Province (28.6 per cent).

\section{CONCLUSION}

This study, which sought to clarify the application of 'Place' and its associated vocabulary by discipline and in relation to geographical entities, is considered timely as the discipline of Place Branding has become increasingly important for practitioners and is receiving more attention from researchers. Researchers have emphasised the need for an agreed vocabulary in the place-branding arena.

The research has revealed that the focus of discussion for place branding has shifted from tourism to business and marketing; case studies in the discipline of Branding and Business (65.2 per cent) were double that in Tourism (34.8 per cent), with the majority of case studies relating to countries (52.8 per cent) and cities (32.6 per cent).

The content analysis of paper titles and abstracts affirmed that the term 'Destination' is used predominantly in the tourism literature, articulated in various geographical entity forms, shown in Figure 1, and accounting for the majority of case studies, second to which is 'Place'. 'Place' and 'Location' are the most dominant terms used in Branding and Business. The absence of 'Town' as a possible place brand term has been noted (town was generally identified as 'Location'), as was the lack of case-study research relating to towns (6.7 per cent), second to which were regions, states and counties (7.9 per cent), respectively, calling for supplementary research. To describe a city the terms most used were 'Destination' and 'Location', region was mostly described as a 'Destination' and a 'Place' while a country was most described as a 'Destination', 'Place' and a 'Nation' but not as a 'Country'.

With regard to the hierarchical relationship between 'Place' and its associated vocabulary (Figure 1) proposed in this study, a 'Nation' indicated a country while a 'Place' signified towns, cities, regions and countries (or nations) as depicted in Figure 1. A 'Location', however, indicates a place in as far as places are defined as towns, cities and countries but not regions, therefore partially reflecting the relationship depicted in Figure 1.

The study has provided some evidence of academic consensus regarding the application of 'place' and its associated vocabulary; however, the discipline of place branding is a new phenomenon that has yet to be fully investigated. Perhaps, given time, greater 
precision may be observed either implicitly or through the formation of place term definitions.

This was an exploratory study; therefore, further research should be undertaken to confirm findings. The content analysis conducted in the study serves as a primary starting point for a more comprehensive empirical research, and further discussion of the use and definition of the terminology of place branding. Future research should consider repetition with the view of obtaining valid and rigorous chi-square results for the purpose of developing clear 'Place' and associated vocabulary usage and therefore definitions. Additionally, research should consider using multi-method data collection, which may include surveys, focus groups and interviews with academics undertaking place-branding research in order to confirm and extend the findings of the study.

\section{Notes}

1 Destination Branding: creating the unique destination proposition by N. Morgan, A. Pritchard and R. Pride (2002, 2004); Brand New Justice: the upside of global branding by S. Anholt (2003); National Image and Competitive Advantage: the theory and practice of place branding by E.D. Jaffe and I.D. Nebensahl (2006); Competitive Identity: the new brand management for nations, cities and regions by S. Anholt (2006).

2 The merging of frequency distributions of two or more categorical variables in a single table for the purpose of understanding how one variable relates to other variables.

3 A minimum expected cell frequency of 5 or more or at least 80 per cent is needed not to violate the assumption of the chi-square.

\section{References}

Anholt, S. (2002) 'Foreward to the special issue on place branding', Journal of Brand Management, Vol. 9, No. 4, pp. 229-239.

Anholt, S. (2005) 'Editorial: Some important distinctions in place branding', Place Branding, Vol. 1, No. 2, pp. 116-121.

Baloglu, S. and McCleary, K. W. (1999) 'U.S. international pleasure traveller's images of four Mediterranean destinations: A comparison of visors and non-visitors', Journal of Travel Research, Vol. 38, No. 2, pp. 144-152.

Blain, C., Stuart, E. L. and Ritchie, J. R. B. (2005) 'Destination branding:Insights and practices from destination management organisations', Journal of Travel Research, Vol. 43, No. 4, pp. $328-338$.

Bradley, A., Hall, T. and Harrison, M. (2002) 'Selling cities: Promoting new images for meeting tourism', Cities, Vol. 19, No. 1, pp. 61-70.

Bramwell, B. and Rawding, L. (1996) 'Tourism marketing images of industrial cities', Journal of Tourism Research, Vol. 23, No. 1, pp. 201-221.
Cai, L. (2002) 'Cooperative branding for rural destinations', Annals of Tourism Research, Vol. 29, No. 3, pp. 720-742.

Cambridge Dictionary Online. available at: http://dictionary. cambridge.org, accessed 09/02/2007.

Chalpin, L., Green, B. and Hill, B. (2003) 'Affects of sports event media on destination image and intension to visit', Journal of Sports Management, Vol. 17, No. 3, pp. 214-234

Curtis, J. (2001) 'Branding a state: The evolution of brand Oregon', Journal of Vacation Marketing, Vol. 7, No. 1, pp. $75-81$.

Dinnie, K. (2004) 'Place branding: Overviews of emerging literature', Place Branding, Vol. 1, No. 1, pp. 106-110.

Gibson, C. and Davidson, D. (2004) 'Tamworth, Australia's country music capital: Place marketing, rurality and residents reactions', Journal of Rural Studies, Vol. 20, No. 4, pp. 387-404.

Gilmore, F. (2002a) 'A Country - Can it be repositioned? Spain - The success story of country branding', Brand Management, Vol. 9, No. 4-5, pp. 281-293.

Gilmore, F. (2002b) 'Branding for success', in Morgan, N., Pritchard, A. and Pride, R. (eds) 'Destination Branding: Creating the Unique Destination Proposition', 1st edn, Butterworth Heinemann, Oxford, UK, pp. 57-65.

Gnoth, J. (2002) 'Leveraging export brands through a tourism destination brand', Journal of Brand Management, Vol. 9, No. $4-5$, pp. $262-280$.

Gnoth, J. (2004) 'Opinion pieces: Where is place branding heading', Place Branding, Vol. 1, No. 1, pp. 12-35.

Hall, J. (2004) 'Branding Britain', Journal of Vacation Marketing, Vol. 10, No. 2, pp. 171-185.

Hankinson, G. (2001) 'Location branding: A study of the branding practices of 12 English cities', Journal of Brand Management, Vol. 9, No. 2, pp. 127-142.

Hankinson, G. (2005) 'Destination brand images: A business tourism perspective', Journal of Services Marketing, Vol. 19, No. 1, pp. 24-32.

van Ham, P. (2001) 'The rise of the brand state: The postmodern politics of image and reputation', Foreign Affairs, Vol. 80, No. 5, pp. 2-6.

van Ham, P. (2004) 'Opinion pieces: Where is place branding heading', Place Branding, Vol. 1, No. 1, pp. 12-35.

Hudson, S. and Ritchie, B. (2006) 'Promoting destinations via film tourism: An empirical identification of supporting marketing initiatives', Journal of Travel Research, Vol. 44, No. 4, pp. 387-396.

Hunt, J. D. (1975) 'Image as a factor in tourism development', Journal of Travel Research, Vol. 13, No. 3, pp. 1-7.

Johns, N. and Mattsson, J. (2005) 'Destination development through entrepreneurship: A comparison of two cases', Tourism Management, Vol. 26, No. 4, pp. 605-616.

Kavaratzis, M. (2004) 'From city marketing to city branding: Toward a theoretical framework for developing city brands', Place Branding, Vol. 1, No. 1, pp. 58-73.

Kavaratzis, M. and Ashworth, G. (2005) 'City branding: An affective assertion of identity or a transitory marketing trick', Tijdschrift voor Economische en Sociale Geografie,Vol. 96, No. 5, pp. 506-614.

Kerr, G. (2006) 'From destination brand to location brand', Journal of Brand Management, Vol. 13, No. 4-5, pp. 276-283.

Kotler, P. (2004) 'Opinion pieces: Where is place branding heading', Place Branding, Vol. 1, No. 1, pp. 12-35. 
Kotler, P., Armstrong, G., Saunders, J. and Wong, V. (2002) 'Principals of Marketing', 3rd European edition, PrenticeHall, Essex, England, UK.

Kotler, P., Haider, D. H. and Rein, I. (1993) 'Marketing Places: Attracting Investment, Industry and Tourism to Cities, States and Nations', The Free Press, New York, NY.

Kotler, P. and Gertner, D. (2002) 'Country as a brand, product and beyond: A place marketing and brand management perspective', Journal of Brand Management, Vol. 9, No. 4-5, pp. 249-261.

Lodge, C. (2004) 'Opinion pieces: Where is place branding heading', Place Branding, Vol. 1, No. 1, pp. 12-35.

Lodge, C. (2006) 'Opinion pieces: How has place branding developed during the year that place branding has been in publication', Place Branding, Vol. 2, No. 1, pp. 6-17.

Low, G. S. and Ronald, A. F. (1994) 'Brands, brand management and the brand manager system: A critical historical evaluation', Journal of Marketing Research, Vol. 31, No. 2, pp. 173-190.

Malhotra, N. (2004) 'International Edition - Marketing Research: An Applied Orientation', 4th edn, Pearson, Prentice-Hall, Upper Saddle River, NJ.

McGnally, M., Martha, R. and De Chernatony, L. (1999) 'The evolving nature of branding: Consumer and managerial considerations', Academy of Marketing Services Review, Vol. 3, No. 2, pp. 1-26.

Morgan, N. (2003) 'Destination branding and role of stakeholders', Journal of Vacation Marketing, Vol. 9, No. 3, pp. 285-299.

Morgan, N. (2004) 'Opinion pieces: Where is place branding heading', Place Branding, Vol. 1, No. 1, pp. 12-35.

Morgan, N. (2006) 'Opinion pieces: How has place branding developed during the year that place branding has been in publication', Place Branding, Vol. 2, No. 1, pp. 6-17.

Morgan, N., Pritchard, A. and Pride, R. (2004) 'Destination Branding: Creating the Unique Destination Proposition', Butterworth Heinemann, Oxford, UK.

Olins, S. (2002) 'Branding the nation state - The historical context', Journal of Brand Management, Vol. 9, No. 4-5, pp. 241-248.

Olins, W. (2003) 'Hull: Pioneering city', Case Study, available at: www.wolff-olins.com/files/Hull_0202New815000.pdf, accessed 09/07/2007.

O'Leary, S. and Deegan, J. (2005) 'Ireland's image as a tourism destination in France:Attribute importance and performance', Journal of Travel Research, Vol. 43, No. 3, pp. 247-256.

Paddison, R. (1993) in Avraham, E. (2004) 'Media strategies for improving an unfavourable city image', Cities, Vol. 21, No. 6, pp. 471-479.

Pallant, J. (2006) 'SPSS: Survival Manual', 2nd edn, Open University Press, Berkshire, UK.

Park, S. -Y. and Petrick, J. F. (2006) 'Destinations' perspectives of branding', Annals of Tourism Research, Vol. 33, No. 1, pp. 262-265.
Parkerson, B. and Saunders, J. (2005) 'City branding: Can goods and services branding models be used to brand cities', Place Branding, Vol. 1, No. 3, pp. 242-264.

Papadopoulos, N. and Heslop, L. (2002) 'Country equity and country branding: Problems and prospects', Journal of Brand Management, Vol. 9, No. 4, pp. 294-314.

Rainisto, S. (2004) 'Opinion pieces: Where is place branding heading', Place Branding, Vol. 1, No. 1, pp. 12-35.

Ritchie, B. J. R. and Ritchie, R. J. B. (1998) 'The branding of tourism destinations: Past achievements and future challenges', Report presented to the 1998 Annual Congress of International Association of Scientific Experts in Tourism, Marrakech, Morocco, pp. 1-31, available at: http://people. commerce.ubc.ca/phd/ritchie/Papers/AIEST1998.pdf, accessed 09/07/2007.

Roberts, L. and Hall, D. (2001) in Bayne, S. and Hall, D. (2004) 'Place promotion through food and tourism: Rural branding and the role of websites', Place Branding, Vol. 1, No. 1, pp. 80-92.

Sharples, A. (2003) 'Cider and the marketing of tourism experience in Somerset, England:Three case studies', Journal of Travel Tourism Marketing, Vol. 14, No. 3/4, pp. 49-60.

Smith, A. (2005) 'Re-imaging the city: The value of sports initiatives', Annals of Tourism Research, Vol. 32, No. 1, pp. 217-236.

Sundaram, U. (2007) 'Place branding in atypical geo-spatial constructs: Property and predisposition', unpublished paper presented at the Academy of Marketing Conference 2007.

Telstrom, R., Gustafsson, I. and Mossberg, L. (2006) 'Consuming heritage: The use of local food culture in branding', Place Branding, Vol. 2, No. 2, pp. 130-143.

The Hat Factory: Destination Branding. available at: www. destinationbranding.co.uk, accessed: 09/07/2007.

Trueman, M., Klemm, M. and Giroud, A. (2004) 'Can a city communicate? Bradford as a corporate brand', Corporate Communications: An International Journal, Vol. 9, No. 4, pp. 317-330

Ulaga, W., Shorma, A. and Krishnan, R. (2002) 'Plant location and place marketing: Understanding the process from the business consumer's perspective', Industrial Marketing Management, Vol. 31, No. 5, pp. 393-401.

Wang, Y. and Fesenmaier, D. (2006) 'Collaborative destination marketing: A case study of Elkhart County, Indiana', Tourism Management, Vol. 28, No. 3, pp. 863-875.

Waragenau, A. and Che, D. (2006) 'Wine tourism development and marketing strategies in South West Michigan', International Journal of Wine Marketing, Vol. 18, No. 1, pp. 45-60.

Whisper: Brand Strategy Consultants. available at: www. whisperbrand.com/blog/category/nation-placebranding, accessed: 09/07/2007.

Wilson, S., Fesenmaier, D. R., Fesenmaier, J. and van Es, J. C. (2001) 'Factors for success in rural tourism development', Journal of Travel Research, Vol. 40, No. 2, pp. 132-138.

Wood, L. (2000) 'Brands and brand equity: Definition and management', Management Decision, Vol. 38, No. 9, pp. 662-669. 


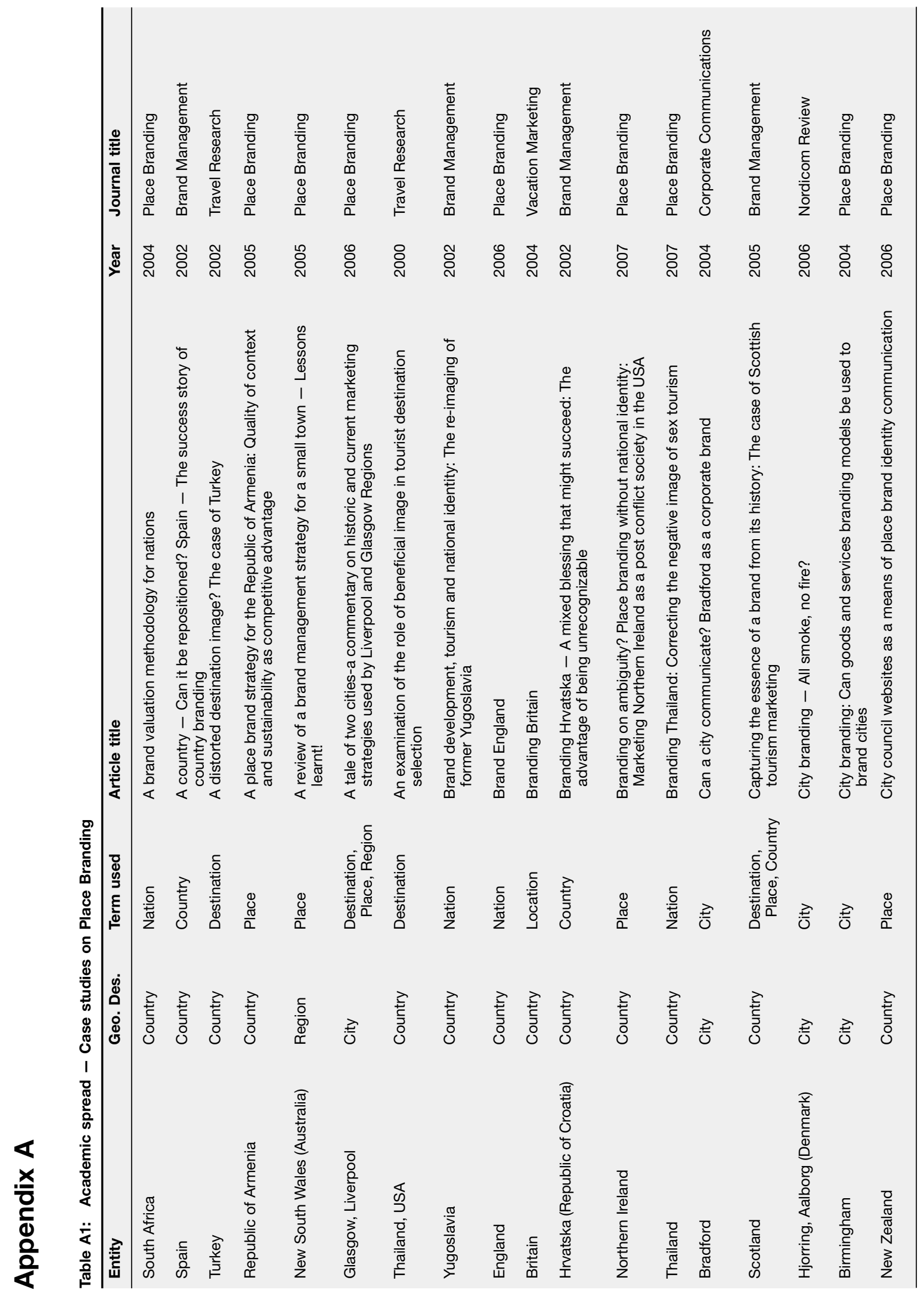




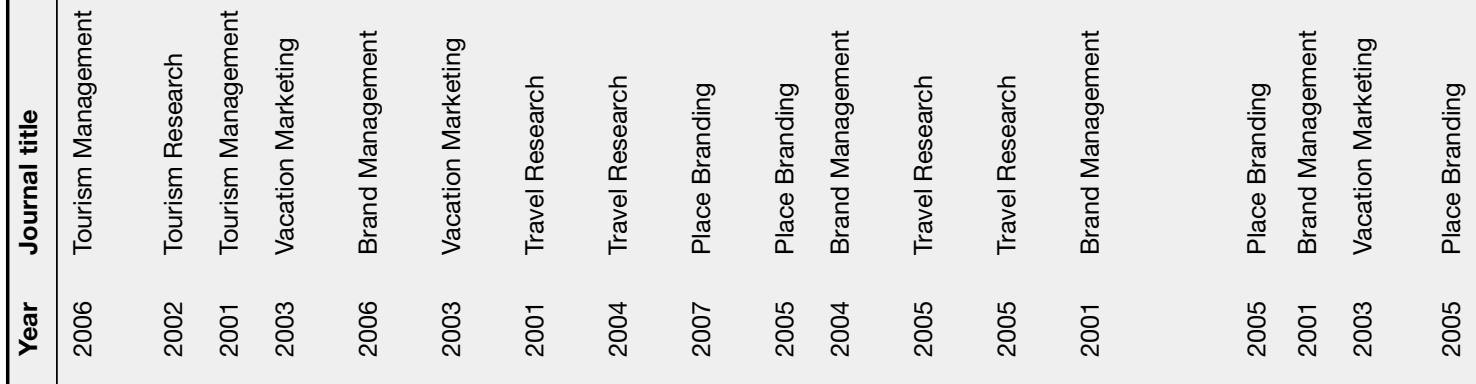

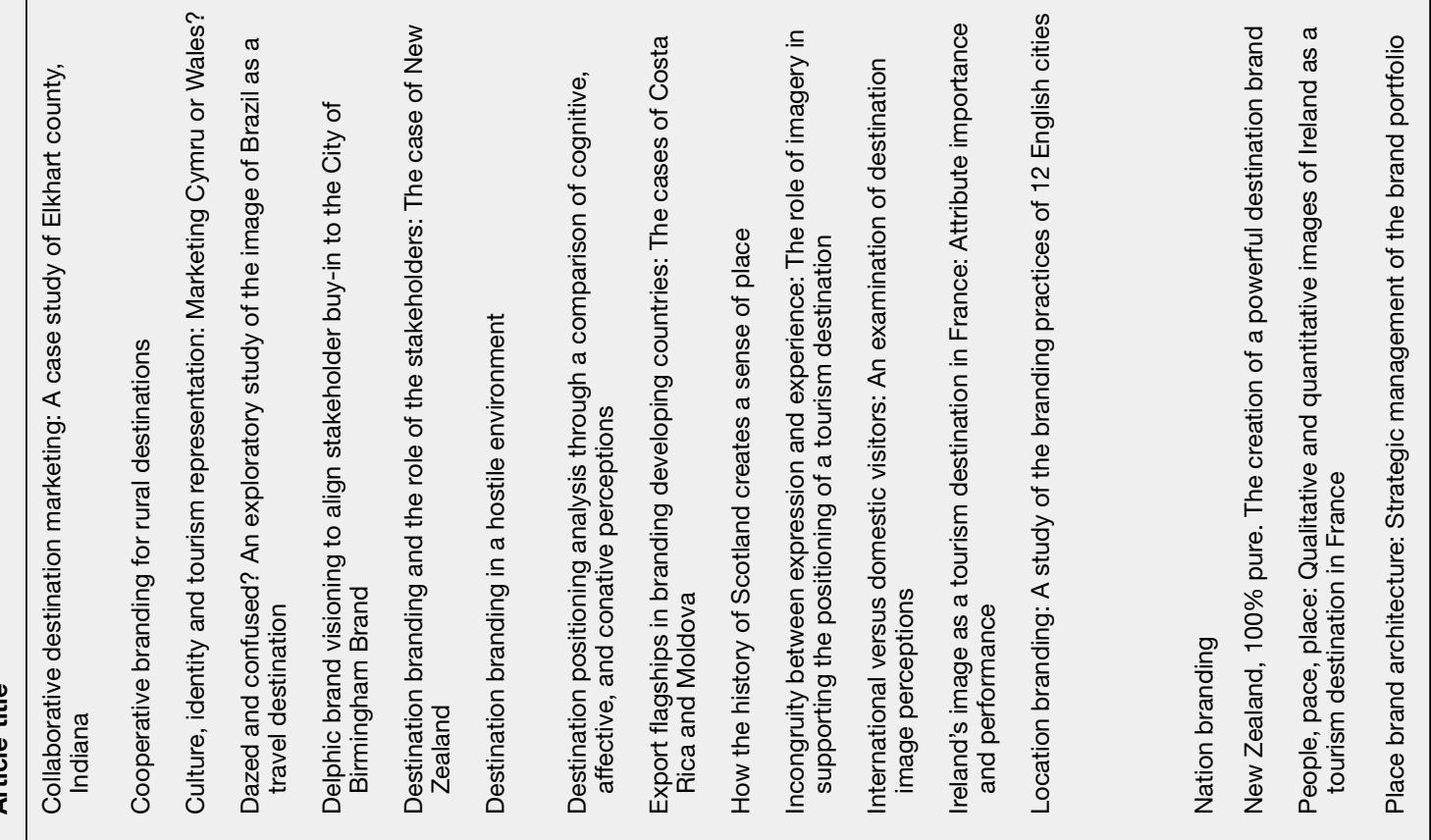

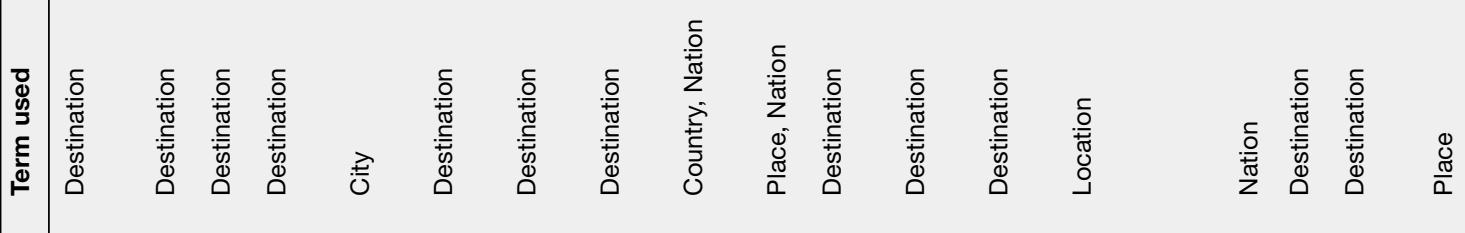

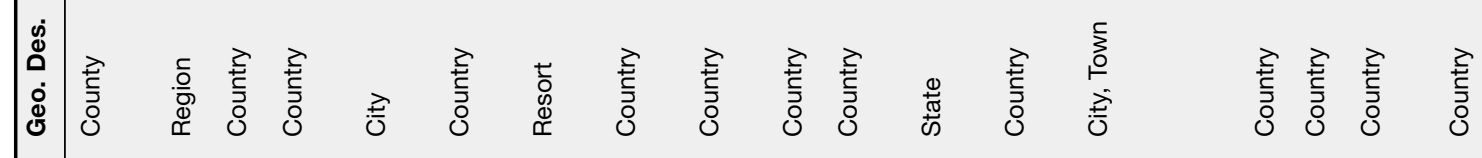

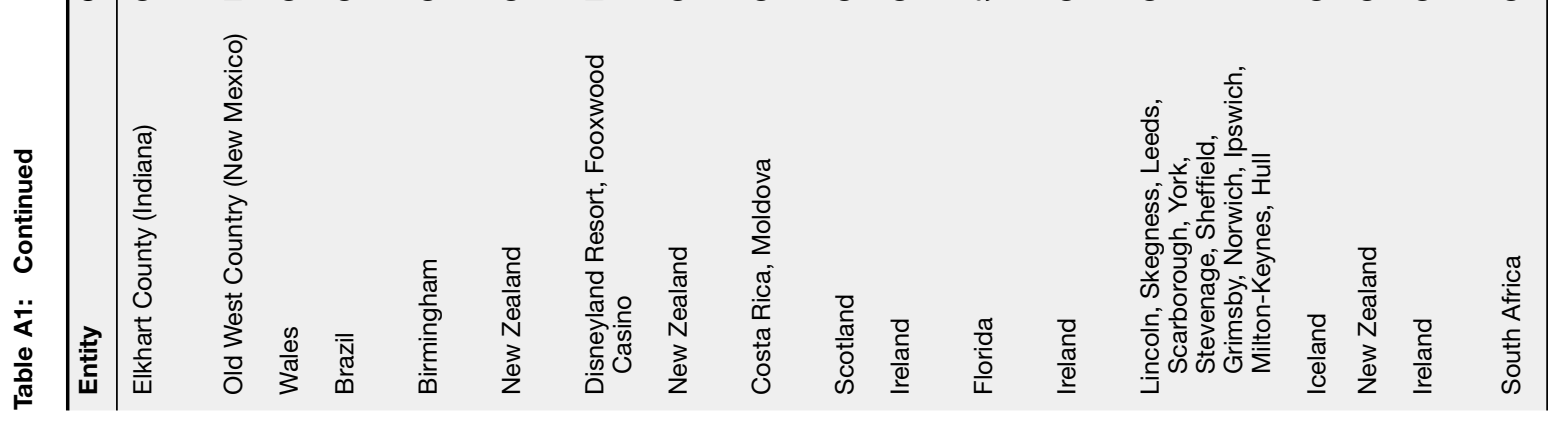




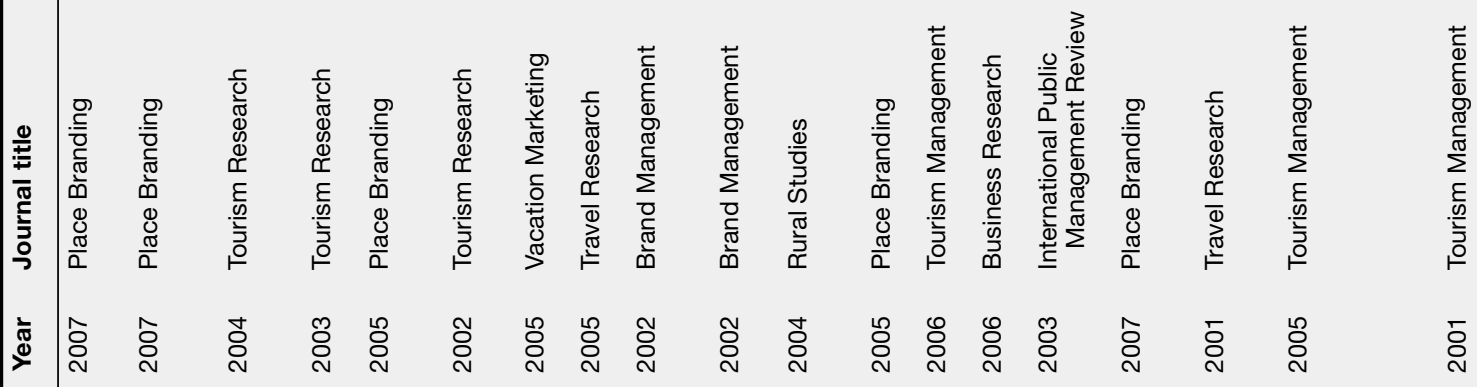

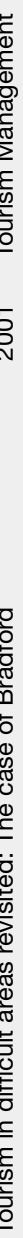

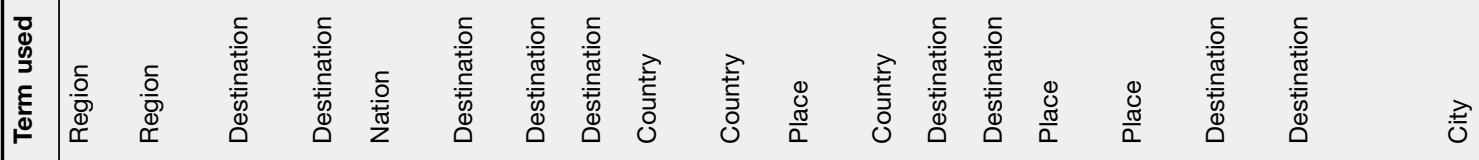

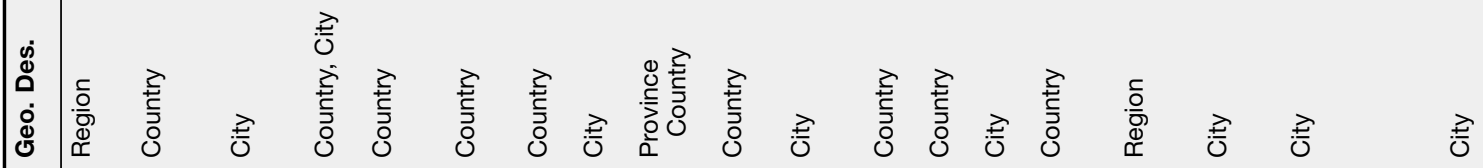

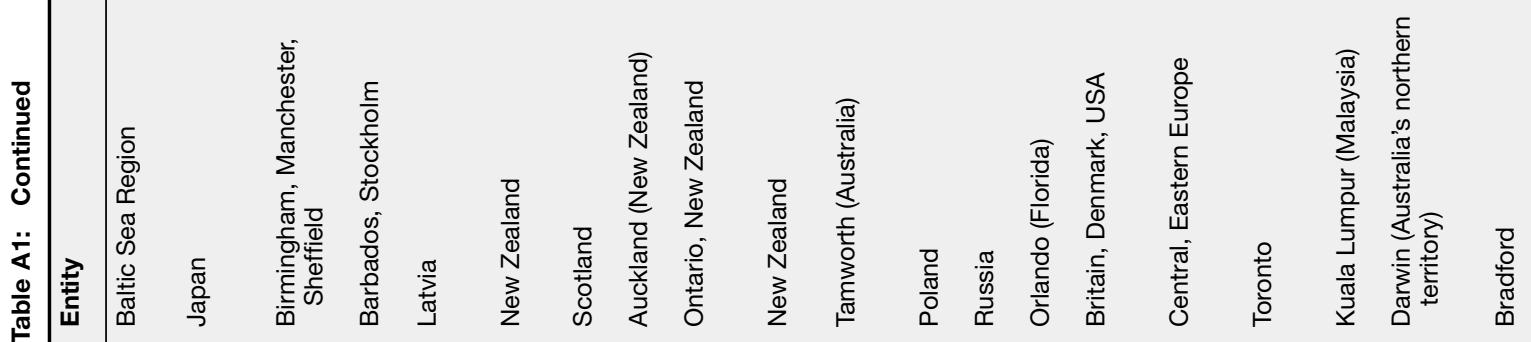




\section{Appendix B}

Table B1:

\begin{tabular}{lcrl}
\hline & Value & df & $\begin{array}{l}\text { Asymp. } \\
\text { (two-sided) }\end{array}$ \\
\hline $\begin{array}{l}\text { Pearson chi-square } \\
\text { Likelihood ratio }\end{array}$ & $177.53^{\star}$ & 60 & 0.000 \\
Linear-by-linear & 149.95 & 60 & 0.000 \\
$\quad$ association & 0.094 & 1 & 0.759 \\
$N$ of valid cases & 91 & & \\
\hline
\end{tabular}

*Seventy-five cells (97.4 per cent) have an expected count less than five. The minimum expected count is 0.04 .

Table B2:

\begin{tabular}{lrrl}
\hline & Value & df & $\begin{array}{l}\text { Asymp. Sig. } \\
\text { (two-sided) }\end{array}$ \\
\hline Pearson chi-square & $81.988^{\star}$ & 42 & 0.000 \\
Likelihood ratio & 75.577 & 42 & 0.001 \\
Linear-by-linear & 0.425 & 1 & 0.515 \\
$\quad$ association & & & \\
$N$ of valid cases & 91 & & \\
\hline
\end{tabular}

${ }^{*}$ Fifty-one cells (91.1 per cent) have an expected count less than five. The minimum expected count is 0.04 .

Table B3:

\begin{tabular}{|c|c|c|c|}
\hline & Value & df & $\begin{array}{l}\text { Asymp. Sig. } \\
\text { (two-sided) }\end{array}$ \\
\hline Pearson chi-square & $59.728^{\star}$ & 6 & 0.000 \\
\hline Likelihood ratio & 71.439 & 6 & 0.000 \\
\hline $\begin{array}{l}\text { Linear-by-linear } \\
\text { association }\end{array}$ & 0.127 & 1 & 0.721 \\
\hline$N$ of valid cases & 89 & & \\
\hline
\end{tabular}

*Seven cells (50.0 per cent) have an expected count less than five. The minimum expected count is 1.39 .

Table B4:

\begin{tabular}{llrl}
\hline & Value & df & $\begin{array}{l}\text { Asymp. Sig. } \\
\text { (two-sided) }\end{array}$ \\
\hline Pearson chi-square & $60.115^{\star}$ & 18 & 0.000 \\
Likelihood ratio & 62.122 & 18 & 0.000 \\
Linear-by-linear & 1.152 & 1 & 0.283 \\
$\quad$ association & & & \\
$N$ of valid cases & 89 & & \\
\hline
\end{tabular}

*Twenty-three cells (82.1 per cent) have an expected count less than five. The minimum expected count is 0.27 . 